\title{
ACTIVITIES OF PUBLIC ORGANIZATIONS FOR THE SPIRITUAL FORMATION OF YOUTH ${ }^{1}$
}

\author{
Zhyhaylo N. I., Ryzhak L. V.
}

\section{INTRODUCTION}

At the current stage of society's development, the role of public organizations is becoming increasingly important. A public organisation is a community created by citizens to promote and protect their collective collective interests. Public organizations are called non-governmental, nongovernmental organizations. In other words, a non-governmental organization is an independent association of citizens, which can help the community to better organize, unite, enrich community spiritually and culturally, and so on.

In Ukraine, as in every country in the world, there are many different types of public organizations. These are professional unions, women's, youth, veterans', children's organizations, scientific, technical, cultural and educational, physical and sports and other voluntary associations of citizens, creative unions, associations, foundations, associations and more. They may have different names: organization, association, union, society, club, circle, council, foundation, association, etc. Their common features are voluntary association, the presence of a certain organizational structure and activity on the basis of self-government. Another feature of a public organization is its non-profit nature (non-commercial) - it should not carry out economic activities for getting profit, otherwise it should be registered with an authorized body of public authority as an entrepreneurial structure.

Such organizations include the Lviv Regional Branch of the All-Ukrainian Public Organization "Society of Psychologists of Ukraine" and the Ukrainian Association of Catholic Teachers. With the initiative of the Head of the Youth Commission of the Ukrainian Greek Catholic Church and the blessing of His Beatitude Lubomyr Husar - Head and Father of the Ukrainian Greek Catholic Church and His Eminence Archbishop and Metropolitan of Lviv Bishop Ihor Vozniak a voluntary, democratic, independent public association was formed, the founders of which became: Commission on Youth Affairs of UKRAINIAN GREEK CATHOLIC CHURCH (on the one hand) and higher education teachers (on the other), Ukrainian Association of Catholic Teachers. At the same time, the Lviv Regional Branch of the All-Ukrainian Public

\footnotetext{
${ }^{1}$ Максименко С.Д. Генеза здійснення особистості : наук. монографія. К. : КММ, 2006. $255 \mathrm{c}$.
} 
Organization "Society of Psychologists of Ukraine" was approved at the Congress of Psychologists of Ukraine in Kyiv ${ }^{1}$.

At these events, almost simultaneously, on April 19, 2010, at about 2 pm, the Ukrainian Association of Catholic Teachers was formed at the Constituent Assembly, and approved at the Congress of Psychologists by a member of the Presidium of the Society of Psychologists of Ukraine, and, consequently, the chairman of the Lviv Regional Branch of the All-Ukrainian Public Organization "Society of Psychologists of Ukraine". So, this day became the day of founding of two public organizations, the head of which was elected Doctor of Psychological Sciences, Professor of Ivan Franko National University of Lviv, Natalia Zhyhaylo ${ }^{2}$.

The purpose of activities of public organizations: the Ukrainian Association of Catholic Teachers and the Lviv Regional Branch of the All-Ukrainian Public Organization "Society of Psychologists of Ukraine" is the issue of spiritual formation of a person at a young age while studying in institutions of higher education; principles of affirmation of ideas of humanism and patriotism; appeals to universal and national values, etc.

Now public organizations are celebrating their decade. Thanks to the activities of two public organizations: Lviv Regional Branch of the AllUkrainian Public Organization "Society of Psychologists of Ukraine" and the Ukrainian Association of Catholic Teachers, assistance to the leadership of Ivan Franko National University of Lviv and the goodwill of numerous colleagues, students, postgraduates International scientific-practical conferences, a number of round tables, workshops, public lectures, trainings, creative evenings and more. Here are the most interesting and important ones.

\section{Lviv Regional Branch of the All-Ukrainian Public Organization "Society of Psychologists of Ukraine" activity}

On April 19, 2007, a scientific-practical conference "Spiritual and cultural values of student youth - revival and affirmation" was held with the participation of Father-Superior of the Church of the Holy Trinity Stepan Kashchuk and People's Artist of Ukraine Bohdan Kozak.

On April 19, 2009 the International Scientific and Practical Conference "The Modern Paradigm of Management and the Ostroh Bible" was held with the participation of the translator of the Ostroh Bible from Church Slavonic into Ukrainian, Doctor of Theology, Head of the Department of Theology of the National University "Ostroh Academy", Archimandry Professor Rafail Turkonyak's father. The design of the conference, and especially its topic,

\footnotetext{
${ }^{2}$ Жигайло Н.І. Психологія духовного становлення особистості майбутнього фахівця : Монографія. Львів : Видавничий центр ЛНУ імені Івана Франка, 2008. 336 с.
} 
was not accidentally interested in a wide range of scholars, because it is devoted to the leading idea of governance, which originates from the Book of Genesis - Holy Scripture, which is based on the Laws of God, which leads to the goal. Father Professor Rafail Turkonyak as a Prophet of the Truth of God is a prime example of moral and spiritual growth for the younger generation. The Great Book - the Ostroh Bible - given by his father-professor for more than 30 years of tireless, persistent, continuous work.

On December 3, 2010, the International Scientific and Practical Conference of Students and Young Scientists on the topic "Faith and Reason" was held at the Ivan Franko National University of Lviv. spiritual formation of personality in terms of market relations; ideological values in the paradigm of modern management; religion and morality in the functioning of the rule of law; people in the age of modern technogenic civilization, globalization and European integration processes, etc.

On December 11, 2010 the second stage of the All-Ukrainian Scientific and Practical Conference of Students and Young Scientists on the topic "Faith and Reason" took place in Kyiv. The Head of the Ukrainian Greek Catholic Church, His Beatitude Lubomyr Husar, as well as the Blessed Bishop Yosif Milian, Bishop Assistant to the Kyiv Archdiocese of the Ukrainian Greek Catholic Church, blessed the event.

On April 19, 2012 the International Scientific and Practical Conference "Science and Spirituality in the System of Modern Management" was held with the blessing of the Bishop of the Ukrainian Greek Catholic ChurchBishop Igor Voznyak. The areas of work of the conference were: modern social progress and management: values; managing the processes of spiritual formation of the individual; ideological values in the paradigm of modern management; The Papal Encyclical of the Gospel of Life and Other Christian Doctrines in the Context of the Problems of the Present Time; development of science and spirituality in the age of globalization and technogenic civilization.

On March 5, 2013 the Academic celebration of the anniversary of the scientific activity of the Honorary Member of the Association, the founder and long-time head of the Department of Sociology, Professor Andriy Khoronzhiy took place. The conference addressed the following issues: theoretical, methodological and organizational foundations of the management culture; organizational and business culture in the context of social development; economic aspects of management culture; sociopsychological factors of managerial culture, etc.

On October 20, 2014, the Scientific and Practical Conference "Management Organization: Origins, Realities and Prospects for Development" was held, dedicated to the 50th anniversary of the scientific 
activity of the long-time manager of the Department of Management, Professor Volodymyr Yatsura. The main directions of the conference were: the emergence, formation and development of management as a human activity; strategic changes in management organization; management culture in the system of economic development of Ukraine; innovative approaches to the formation of management personnel; professional and spiritual formation of manager's personality.

Since 2015, we have started a series of conferences, which I call: The Rector's Project. Thus, proposing the title: "Psychological Aspects of Spirituality", Rector Volodymyr Melnyk added: "Philosophical and Psychological Aspects of Spirituality". Therefore, on April 19, 2015, the First All-Ukrainian Scientific and Practical Conference was held: "Philosophical and psychological aspects of spirituality: socio-economic transformations and the revival of national dignity". The directions of the conference were: philosophy of the Dignity Revolution and Euromaidan; building a nation-state in the writings of Andrey Sheptytsky; philosophical and legal foundations of spirituality; psychology of the spiritual personality: geographical context; philosophical aspects of management culture; intercultural communication in the context of European integration; economic problems of strengthening Ukrainian statehood.

The conference brought together experts from various fields of science: philosophy, psychology, economics, administration, law, clergy and other fields. What is decisive is that this event took place in the year of Metropolitan Andrey Sheptytsky - the outstanding theologian, Master of the Church, the spiritual guide of our people, named by us "the native Moses" and is dedicated precisely to the year of Metropolitan Andrew, ie 150 from the day of his birth.

What is unique is that we had the happy opportunity to receive the blessing of today the head of our church - the successor of the case of the great Metropolitan Andrey Sheptytsky - our Archbishop and Metropolitan of Lviv Bishop Igor! Significant for me personally (and for us) is the presence of a well-known scientist of today, a meter of psychological science in Ukraine and abroad, a giant of spirit, soul, mind and heart, the director of a powerful scientific center in Ukraine - known to all by the GS Kostyuk Institute of Psychology National Academy of Pedagogical Sciences of Ukraine, Teacher of My Life - Academician Sergey Maksymenko.

Very grateful to have arrived: Professor Volodymyr Morgun from the Korolenko National Pedagogical University of Poltava, who largely applied to the idea of holding today's conference, Professor Myroslav Savchyn - the founder and luminary of the direction of spiritual psychology, Father Sebhtak and the activities of Metropolitan Sheptytsky, the head of the commission of 
the sacred art of the UKRAINIAN GREEK CATHOLIC CHURCH, and to all those today who will make interesting in-depth reports.

Also interesting is what the conference date is all about: the fact is that 5 years ago - April 19, 2010 - two independent events took place - in Lviv and in Kiev - the Constituent Assembly of the Association of Catholic Teachers and The Congress of Psychologists of Ukraine, at which, almost simultaneously (about 14 hours) and thus - (one formed, the other modified and continued its work) - two public organizations. Thus, this day became the day of foundation of two public organizations: the Association of Catholic Teachers and the Lviv Regional Branch of the All-Ukrainian Public Organization "Society of Psychologists of Ukraine", and I was elected chairman. Today's event for me is a kind of report for the 5-year activity of two public organizations: the Lviv Regional Branch of the All-Ukrainian Public Organization "Society of Psychologists of Ukraine" and the Ukrainian Association of Catholic Teachers, each with its own history. Recently, a memory conference was held at Tsurkovsky's University of Physics, which headed the Lviv Zonal Society of Psychologists from 1969 to 1995. As for UAVC, her idea somewhere up there, perhaps, came about when, when she was a student at the faculty, she was officially allowed to write a course in psychology as an exception at the faculty - thank you for that, Yaroslav Pryguli. Or, when she began her professional activity at 69 schools in Lviv, she initiated the founding of the Church, which now really exists and serves the people, and was dedicated on May 24 by the name of Cyril and Methodius - Slavic educators and the church. Or maybe when she went to work at a medical college at Doroshenko street, or at the department of sociology or management - and more than once she was the initiator of conferences on spiritual topics. And, maybe, when for the first time in 6th grade I saw the construction of LNU and the soul remained in it. This remains a philosophy, but at all stages, the leading activity was the formation of spirituality. That is why the present date of the conference is explained. The conference was conceived as a backstage chamber event, but thanks to all of you - it became a serious event. Because the topic is relevant, contemporary, interesting, important. Thank you to everyone who supported the idea, who joined it. We expect the conference to confirm the direction of spiritual psychology. And the future of our science, nation and state will depend on it.

On November 27, 2015, the All-Ukrainian Scientific and Practical Conference "Security of the Ukrainian People in the 21 st Century: Problems, Origins, Solutions" was held. management of human life safety; spirituality as the basis of state formation and economic strengthening; banks of Ukraine as drivers of development of the real economy of the state; place of selfgovernment in the system of administrative and territorial reform in Ukraine; constitutional principles for reforming the Ukrainian state. 
On February 19, 2016, the Second All-Ukrainian Scientific and Practical Conference "Philosophical and Psychological Aspects of Spirituality: Trust as the Basis for Changes in Economy and Society" was held, dedicated to the memory of Heroes of the Heavenly Hundred. Areas of work of the conference: philosophy of heroic deeds of Heavenly Hundred Heroes; memory as a philosophical category and national dignity; trust as the basis of state formation and economic strengthening; psychological aspects of spiritual values in the management system; institutional levers of restoring confidence in the financial system of Ukraine; social responsibility of financial institutions. The conference aims to develop spiritual values, their ideals, views, concepts and its purpose - to build trust as the basis of change in the economy and society, and its dedication - to the memory of the Heavenly Hundred Heroes and all those who give their lives and health for the dominance of this virtue in the modern world.

Our event is multidisciplinary in that it brings together professionals from various fields of science: philosophy, psychology, economics, management, finance, banking, law, theology and other fields. More than 150 abstracts have been sent to the organizing committee, these are scientists from different parts of Ukraine: Lviv, Kiev, Poltava, Ternopil, Ivano-Frankivsk, Chernivtsi, Cherkasy and from abroad. This will enable a thorough and comprehensive study and resolution of the problem. And even more unique is the fact that this topic obviously owes its strength to the society because of the fact that independently of each other at LNU (us) and the Institute of Banking (headed by Mr Sugonyako) the idea of studying such a problem simultaneously arose. God saw this as good, blessed and joined our efforts. So, complementing each other in our good thoughts and noble intentions, today, at the conclusion of our conference, we will hold a joint roundtable to summarize, resolve and exchange views. I will add that the conference of colleagues is entitled: "Creating a Space of Public Trust in the 21st Century Ukraine" and has been ongoing since February 17 at the Institute of Banking at a very high scientific and organizational level.

With their participation they strengthened the conference: professor Myroslav Savchin from Drohobych Ivan Franko State Pedagogical University - founder and affirmator of the department of spiritual psychology, professors of Lviv University: prof. Varij, Mrs Sibirna, prof. Shunevich, Mr. Moiseenko, dear professors and heads of departments of our university. Thank you for taking the time to share your valuable scientific achievements! Significant for us is the presence in this room of Ivan Pazin, the People's Poet, the Record-holder of the Record Book of Ukraine, and the Guinness Book of Records, the father of the hero of the Heavenly Hundred, who will be the first to present his poetic report at our plenary session. 
Thank you to everyone who delivers the report, who directly and indirectly attends the conference, everyone who supported the idea and who contributed to it! My sincere thanks to the Conference Heads: Dear Mr. Rector Volodymyr Melnyk and Honorable Academician Sergei Maksymenko, Dean of the Faculty of Philosophy Lyudmila Rizhak and Dean of the Faculty of Economics Rostislav Mihaylyushy. Special thanks to all the members of the organizing committee (not only the event is interdisciplinary, but also the organizing committee are colleagues from different educational institutions, GS Kostyuk Institute of Psychology of the National Academy of Pedagogical Sciences of Ukraine, Lviv Polytechnic National University, Lviv State University for Life Safety Pedagogical University, united by the Society of Psychologists, the Association of Catholic Teachers, just like-minded)! I would like to thank the colleagues of the department, and especially the chair of the department, Professor Yatsura Volodymyr, for the favorable platform for holding such events. We expect from the conference the approval of philosophical and psychological aspects of spirituality. After all, the Heroic Hundred, having taken the first step, cranked the cranberry key into the eternity of eternity, becoming our Guardian Angels in heaven. And we - the Ukrainian scientific elite - by our indifference to their feat, form the faith, trust and hope as the basis of the spiritual prosperity and economic well-being of our country.

On April 19, 2017, the 3rd All-Ukrainian Scientific and Practical Conference "Philosophical and Psychological Aspects of Spirituality in Economics and Management" was held. Areas of work of the conference: the spiritual aspect of modern science management; business psychology as a prestigious field in psychological science; spirituality and its manifestation in life crisis situations; innovative methods and technologies in education; crosscultural communications, joint educational projects and programs; interdisciplinary and cross-sectoral problems of psychological theory and practice.

Today, all of our best is a renewed nature: physically - as a result of spring and spiritually - through the Resurrection of the Lord; youth audience, optimistic mood, positive attitude, rational orientation! We have the best modern Rector; the young energetic Blessed Bishop Volodymyr Hruza; young cheerful Head and founder of SPE Business Coach Roman Kushnir; wonderful students, wonderful promising young scientists, scientists, teachers, guests!

The topic and purpose of our event is very relevant, because we all want to live in a beautiful, rich, prosperous, prosperous state of Ukraine! And God himself in II Corinthians 9: 8 in this regard says that "... he is able to shower us with all grace, that in all things we may always have what we need, and 
that he may remain in every good work..." And also the great Patriarch Joseph Slipyy said: "Rich in honest earnings, be rich, but also righteous". Reverend Bishop Volodymyr Hruza: "If a business ceases to serve, it ceases to be a business". "Every business is a ministry. In order for it to thrive, you need to know its uniqueness and the value of what you do. The more value you promote, the more resources you will get" - Roman Kushnir.

Therefore, at our conference we want to declare that the economy can be strong and prosperous, business honest and profitable, management wise, fair and patriotic. Our conference must answer the pressing questions: if we are poor, why are we poor; if not successful, why are they unsuccessful? To show that it is not the criticism, insults and accusations of others, but forgiveness, praise, responsibility for one's actions, constant learning, new ideas, goals, plans and necessarily the ability to give thanks that will be a solution to both prosperity and prosperity. Our event is multidisciplinary - bringing together professionals from different fields of science: philosophy, psychology, economics, management, finance, banking, law, theology and other fields. The Organizing Committee received more than 100 abstracts from scientists from different corners of Ukraine: Lviv, Kiev, Poltava, Ternopil, Ivano-Frankivsk, Khmelnytsky, Ostroh and from abroad. This will give an opportunity for a thorough and comprehensive study and solution of this problem. Professors of Lviv and Lviv region, Ukraine and from abroad, distinguished professors and heads of departments of our University have strengthened our participation with our participation. Thank you for taking the time and the opportunity to share your valuable scientific achievements! Thank you to everyone who delivered the report, who directly and indirectly participated in the conference, everyone who supported the idea and who contributed to it! Thank you very much to the Conference Heads for the real effective support of the conference!

Special thanks to the members of the organizing committee - colleagues from different educational institutions - GS Kostyuk Institute of Psychology, National Academy of Pedagogical Sciences of Ukraine, Ivan Franko Drohobych State Pedagogical University, Lviv Polytechnic National University, Lviv State University of Internal Affairs, Lviv State University National Pedagogical University, united by the Society of Psychologists, the Ukrainian Association of Catholic Teachers, are just like-minded

\section{Business and Management Psychology Educational Program}

On March 16, 2018, the International Scientific and Practical Conference "Business Psychology and Management: Challenges of Today" was held. Areas of work of the conference: post-industrial challenges of the modern economy; organizational development: strategies, communications, projects; psychological tools in management; socio-psychological approaches to doing business; modern 
human resources management technologies. Experts from 10 countries: Ukraine, Austria, Germany, Lithuania, Poland, Finland, Georgia, Jordan, Tajikistan, Canada and scientists from 20 universities joined the conference. SoftServe Corporation was the general partner of the conference from business.

On the first day of the event, keynote speakers discussed the role of psychology in business and the transformation of business education at the roundtable. Reports were made by: Taras Kytsmey (The Chairman of the Supervisory Board of LNU, co-founder of SoftServe Corporation, $\mathrm{PhD}$ in Physics and Mathematics, Honored Economist of Ukraine), who outlined the requirements of modern business and changes in education; Natalia Zhyhaylo, Head of the Educational Program "Psychology in Business and Management", informed the conference participants that a Master's program in Business and Management Psychology was launched at Lviv University due to the necessity of the following specialists at the labor market: psychologist-psychometrist in the business system, trader, coach, consultant in psychology of management and communications, PR-manager, HR-manager, recruiter, creative director, teacher of psychology of business and management, etc. She emphasized the competencies that such a specialist should possess and told what was done to develop these skills. She outlined the prospect of opening a specialization "Business and Management Psychology" at Bachelor level. After all, students should start training purposefully, starting with the first year of their study. It is necessary for the successful formation and development of the personal and professional competencies (soft skills) that is required by employers. Head of the School of Sustainable Entrepreneurship Eckhard Kehrein (Germany) emphasized the role of psychology to succeed in business. Founder of Colaboritsi.com, University of Ontario researcher Olena MikhailenkoBlaion (Canada), spoke about organizational training and development of human capital in the post-industrial period. Sandra Velasquez, Practical Psychologist, Business Coach, Lecturer at Webster University (Austria) introduced the issues of psychological counseling for business efficiency. ${ }^{4}$

In the second part of the day, the participants of the conference attended unique workshops from practicing psychologists from Austria and Ukraine: Salvatore Giacomuzzi, Sandra Velasquez and Ihor Lebedinets, who shared psychodiagnostic tools in business, psychosystem decision-making, enrich business philosophy ${ }^{3}$.

On Saturday, March 17, the conference continued its work in the office of the international company SoftServe, where the participants of the event had

3 Kokhan M. Kehrein E. Transfer of European experience in the development of entrepreneurial motivation. Philosophy \& psychology of leadership in business, education and government. March 15, 2019, Lviv. P. 3-6. 
an interesting informative excursion held by the founder of SoftServe Corporation Taras Kytsmey, as well ${ }^{4}$ as a number of reports, in particular, from Renata Chuchmai, Vitaliy Kukharskyj and Eckhard Kehrein.

Teachers and students of economics and philosophy departments, masters of educational program "Psychology of Business and Management" took the most active part in the organization of events. The co-organizers of the conference were the High School of Humanities and Natural Sciences in Sandomierz (Poland), the Webster University in Vienna, the Institute of Psychology, National Academy of Sciences of Ukraine, Turku University (Finland), Kaunas University of Applied Sciences (Lithuania), Lodz University (Poland), Tajik State University of Commerce (Tajikistan), Al-Ahli University of Amman (Jordan), Rzeszow University (Poland), Batumi Maritime Academy (Georgia), Sigmund Freud University (Austria) yholohiv Ukraine and General Partner of the business corporation SoftServe.

The co-ordinators of the conference were Natalia Zhyhaylo, Doctor of Psychological Sciences, Professor, Head of Educational Program "Psychology of Business and Management", Marianna Kokhan, Associate Professor of Management and responsible for the production of conference materials Yuriy Maximets, Associate Professor of Economics of Enterprise.

March 15, 2019: the 4th International Scientific and Practical Conference "Philosophical and Psychological Aspects of Leadership in Business, Education and the State".

Work areas of the conference: spiritual intelligence and values of the leader in society; current challenges in the psychology of business, leadership and communications; innovative management of business projects; psychological techniques for business, leadership and communication; interdisciplinary and cross-sectoral problems of psychological theory and practice.

The topic and purpose of our event is on the agenda, especially on the eve of a momentous event - the presidential election, because we all want to live in a beautiful, rich, prosperous state of Ukraine! And best of all is to quote the words of European Council President Donald Tusk, which are 5 tips for Ukraine $^{5}$ :

${ }^{4}$ Blayone T., Mykhailenko O., Kavtaradze M., Kokhan M., vanOostveen R., Barber W. Profiling the digital readiness of higher education students for transformative online learning in the post-Soviet nations of Georgia and Ukraine. International Journal of Educational Technology in Higher Education. 37 (2018). URL: https://educationaltechnologyjournal.springeropen.com/ articles/10.1186/s41239-018-0119-9

5 Kokhan M. Kehrein E. Transfer of European experience in the development of entrepreneurial motivation. Philosophy \& psychology of leadership in business, education and government. March 15, 2019, Lviv. P. 3-6. 
1. Do not cause excessive harm to each other in the forthcoming elections. Internal conflicts are the biggest gift for opponents. So, argue to the extent and remain united in the questions that matter most to Ukraine!

2. Think carefully about the temptations of radical nationalism and populism, because the foundations of a united Europe (and I would add to the world) are reconciliation, solidarity and historical truth!

3. Everyone stated on their pages on Facebook: "Do not imitate those neighbors and European politicians who want to convince everyone that democracy based on freedom and human rights, respect for minorities, freedom of thought and expression. It's a relic of the past. And now is the time of authoritarian democracy. "But few have come to the fore: "We must protect fundamental values!"

4. Let us build a virtuous state together.

5. Believe in the youth.

So, today's conference wants to declare that the economy can be strong and prosperous, education - prestigious and profitable, state formation - wise, fair and patriotic. Our conference must prove that not criticism, insults and accusations of others, but forgiveness, praise, responsibility for our actions, constant learning, new ideas, goals, plans and, surely, gratitude is a model and a path to prosperity! Our event is multidisciplinary and it brings together experts from different scientific fields and its participants are scientists from various corners of Ukraine: Kyiv, Lviv, Poltava, Odesa, Kamenets-Podilsky, Drohobych, Ternopil, Ivano-Frankivsk, Ostroh, Vinnytsia and from abroad. Thanks to everyone who took the time and opportunity to share their valuable scientific work!

Thank you very much to the Conference Heads for your real effective support! To the members of the organizing committee! Thanks to Yuriy Maksymets for his careful work on conference materials. Thanks to my native University for the auspicious platform for these events. We expect the conference to endorse the philosophical and psychological aspects of leadership in economics, education and the state. After all, the millennial heroic history of our country and the modern modern Heroes and all who are currently risking their lives for our future, obliges us, the Ukrainian scientific elite, to the efficiency and effectiveness of our work as the basis of prosperity and economic well-being of our state. And we present this Ukrainian scientific elite with you dear scientists, dear participants of the conference! Every nation, every state, every institution and organization have its leader and statesmaker! The one who leads! The one that is ahead! The one that always wins! One that is endowed with specific leadership characteristics: initiative, foresight of views and ideas; openness to people; perseverance and perseverance throughout. 
For our university such Leader is its Rector Volodymyr Melnyk. Distinguished Scientist, Doctor of Philosophy, Professor, Corresponding Member of the National Academy of Pedagogical Sciences of Ukraine, Honored Worker of Science and Technology of Ukraine, Honored Professor of the University, Rector of Ivan Franko National University of Lviv Volodymyr Melnyk did a lot to the development of national and world science; take a part in the formation and prosperity of our Alma Mater; to the endorsement of Lviv University with longlasting traditions and powerful scientific schools in combination with modern innovation trends at the world level. He makes the University open, mobile, creative, innovative, competitive.

The Rector of the University has made a great deal of effort to transform the University's management into effective, progressive management aimed at continually improving the quality of teaching and the development of research.

Rector of the University Volodymyr Melnyk cares about the formation of philosophical and psychological aspects of spirituality of personality of each participant of the process (student, graduate student, teacher); about the development of a high artistic and aesthetic culture and contributes to the comprehensive development of young people, protection and strengthening of their physical, mental and spiritual health.

His particular respect belongs to the formation of patriotic experience in student youth; the promotion of national-patriotic values and respect for the cultural and historical past of Ukraine in the minds of young people.

The rector of the University Volodymyr Melnyk successfully promotes the brand of the University through the presentation in international scientific and educational organizations: participation in international projects and programs; ensure that curricula are in line with European and world standards; develops joint and double degree programs; holds the highest position of the University in the leading world rankings and more.

Professor Melnyk is the author of a large number of scientific and educational-methodical works, among them monographs, textbooks, textbooks, the most important of them, in particular, "Methodological Aspects of Development of Technical Knowledge in the Conditions of Enhancing Integration of Science", "Philosophy of Technical Science: Unity epistemological and subject-transformative", "Philosophy of modern science and technology", "Tolerance as a sociocultural phenomenon: worldviewmethodological aspect", etc.

For many years of conscientious work, Volodymyr Melnyk has received a number of honorary awards: he was awarded the Order of Merit of the 3rd century, Grigory Skovoroda Gold Medal, Honorary Mention "For Professional Achievements", Order of Prince Yaroslav Mudroho and many more. 
Famous to the world in the field of philosophical problems of science, culture, technology, methodology of science, Professor Melnyk is the coordinator of research on the development and use of philosophical methods in the field of personality education and development. Under his guidance, a powerful scientific school of philosophy was created to ensure the development of a general scientific level of methodology in the 21st century.

According to Volodymyr Melnyk, the main philosophical and methodological problems of science and technology are considered through the prism of world realities at the turn of the XX - XXI centuries; the most important aspects of the scientific and technological revolution, modern scientific and integrative processes, their influence on solving global problems of humanity and realization of the concept of sustainable development are analyzed. Much attention of the scientist is paid to informatization of the society and the phenomenon of information culture of the scientist and specialist; tolerance as a sociocultural phenomenon; studying the history of Ukrainian culture; science in the spiritual culture of mankind; the question of man as the focus of all global problems in the modern world.

"Our work is the work of structural units, departments and faculties, but at the heart of everything is Human. I believe that we should all maintain and strengthen the moral and psychological climate of interaction that exists at the University. I wish the team confidence that we are doing a great and necessary thing for Ukraine, its youth and science. That is why I wish you creative life and good health!" - this was the first Rector's wish and these words have been confirmed by Professor Melnyk over the years.

Farsightedness is the most important sign of a leader. Rector of the University Volodymyr Melnyk is a visionary leader who is able to see the future of the University. He has a concrete and realistic idea of the way to go and the goal that is important to achieve. The Rector of the University is endowed with important leadership traits: power of desires, powerful internal impulse, justified optimism, openness to new ideas, competence in time, purposefulness, charisma; responsibility and morality, high spirituality; selfrealization in scientific and management activity, democracy, modesty and uniqueness. The ability to see perspective transforms him into a special Person. "A person can withstand anything, if they have enough weight for what, " - Friedrich Nietzsche.

Ivan Franko National University of Lviv launched its Business Psychology and Management Psychology educational program. This is a unique opportunity to get two Qualifications Master's in Management and Business psychologist. Applicants can be bachelors, specialists and masters of economic specialties, as well as specialties: psychology, sociology, management. In order to popularize the educational program "Psychology of 
Business and Management", a scientific and practical project "Psychological Workshop of Management" (project leader: Doctor of Psychological Sciences, Professor Zhyhaylo N, co-organizers: Assoc. Prof. Kokhan M., Assoc. Danylevych N.).

Many activities have been carried out on this project: a master class "Psychology of anxiety" by Maria Stasiuk, who is a psychologist, a certified Gestalt therapist and a supervisor of the Ukrainian Gestalt Institute, Ukrainian Institute of Gestalt; "System coaching as a tool of personal development" by Galina Karpuk - a famous psychologist, coach; psychological training "Money and Relationships" by Rimma Grishchuk, who is an organizational consultant, system consultant, business trainer, owner of the Center for Business Education and Consulting, $\mathrm{PhD}$ in Economics, practicing psychologist, author and host of leadership programs and seminars, management, personal growth; guest lecture on "HR-manager as a profession" by Lyudmila Levytska - Head of the department of training, internship and practice of personnel management of Lviv city council; Eckhard Kehrein training seminar "Success can be planned", which has become a good lesson for students; Sandra Velasquez, Certified System Business Coach, Consultant, Teacher of Psychology at the University of Webster in Vienna, shared the principles of "Prevention of professional burnout", training of Salvatore Giacomuzzi, Doctor of Psychology, Business Consultant, Professor of the Private University Sigmund Freud (Austria, Italy) "Psychological method of decision making" and the like.

Considerable cooperation with the Committee on Education and Personnel Policy of the Lviv Chamber of Commerce and Industry; Council of Entrepreneurs at CMU, Regional Council of Entrepreneurs in Lviv region; with the Association of Catholic Doctors and more.

Hearts open to God and people! It is in these words - which are the title of today's keynote - I want to address you - which is said - unusual people these ordinary doctors! I sincerely congratulate you on the glorious anniversary of your renowned, revered, highly spiritual Association! Associations known to Ukraine and the world for their significant acts of virtue, their spiritual and educational activities, unprecedented hard work and openness, responsibility and sacrifice, simplicity and refinement, deep intelligence and decency!

It is a pleasure and honor to welcome you to this wonderful day, decorated with frosty freshness, bright sunshine, clearness of the sky, encouraging coolness, at the same time, full of majesty and excitement! After all, just like you, dear followers of St. Luke, who heal the spirit and body of man with the right word and the art of medicine, we, the friendly Association of Catholic Teachers, follow your example of powerful and noble activity! At least half of your path (about 10 years) we learn from you, follow you, follow you by example! 
An example, without exaggeration, of true modern heroism! Indeed, I do not know whether it is still possible to meet such a community, in the eyes of each member of which is so passionately burning a spark of love, dedication, loyalty to its Association and the cause for which it is intended. I have not met this kind of self-organization yet, especially the self-management, the discipline with which you so earnestly hasten to the sciences to your tireless spiritual leader, teacher, mentor, and unique - Father Cornelius! This is a separate page of your large-scale project, but the page is bright, special, deep, incomprehensibly creative, accessible in simplicity and refined in the skill of word and spirit! Thank you, Father Cornelius, for having learned so much from you!

And where to find the words of warmth, love and gratitude worthy of the equally important mover, source, powerful powerhouse of your Association. With what responsibility and admiration, she always conscientiously, accurately, clearly works on the organization of all spiritual events: trips, forgiveness, meetings, recollections.

Honorable President of the Association of Catholic Doctors! I bow my head low to you - always humble, balanced and calm in work - at the same time a powerful founder and explorer, mastermind and benefactor, leader and leader of the Great Spiritual Community! Thank you very much for the grain of true Love, boundless Goodness, deep Wisdom, noble Courage and Divine Sacrifice for people, for people and for the sake of men!

Dear colleagues of the friendly Association! Thank you for repeatedly accepting me (or even us) throughout the exquisite space. Because they shared a sea of impressions and emotions from what they saw, the ocean of pleasure from what was heard, the pinnacle of knowledge of the incomprehensible, as well as a drop of fatigue or even pain from the experience. Each of you are the ones who are faithfully on the guard of the physical and spiritual well-being of man. We know that health outweighs all the benefits of life that, they say, a truly healthy beggar is happier than a sick king. So, thank you for the fact that each of you in his professional skill has the look of a falcon, the girl's hands, the wisdom of a snake and the heart of a lion! I wish you, dear Anniversaries, joy and pleasure! Fulfillment of plans, dreams and ideas! Great creative inspiration and blessing of God in a compelling, tireless, dedicated work to glorify God, the state and the Church! You are deeply recognized, loved and respected by today's society! We are learning from your experience! I hope you always be happy in everything! We are also consistent in our gifts - so we give you the book "The Ukrainian Portrait of the 16th-18th Centuries" with the wish that the next edition of the 21 st Century be a portrait of your Association and its leaders. 


\section{CONCLUSIONS}

Such activities of NGOs have a positive effect on the spiritual development of its members and the student youth with which NGOs work. In order to study the assessment of the level of spiritual development in students, we conducted an experiment. The research contingent consisted of young people studying at higher educational establishments of Lviv region: 305 people were studied during all the years of study at university.

Comparison of the distribution of spiritual levels of students "before" and "after" the implementation of the program of spiritual formation of personality (Fig. 1) illustrated the effectiveness of the applied program. In particular, the share of high levels of spirituality in youth has increased by $20 \%$ (due to the implementation of the program of spiritual formation of personality).

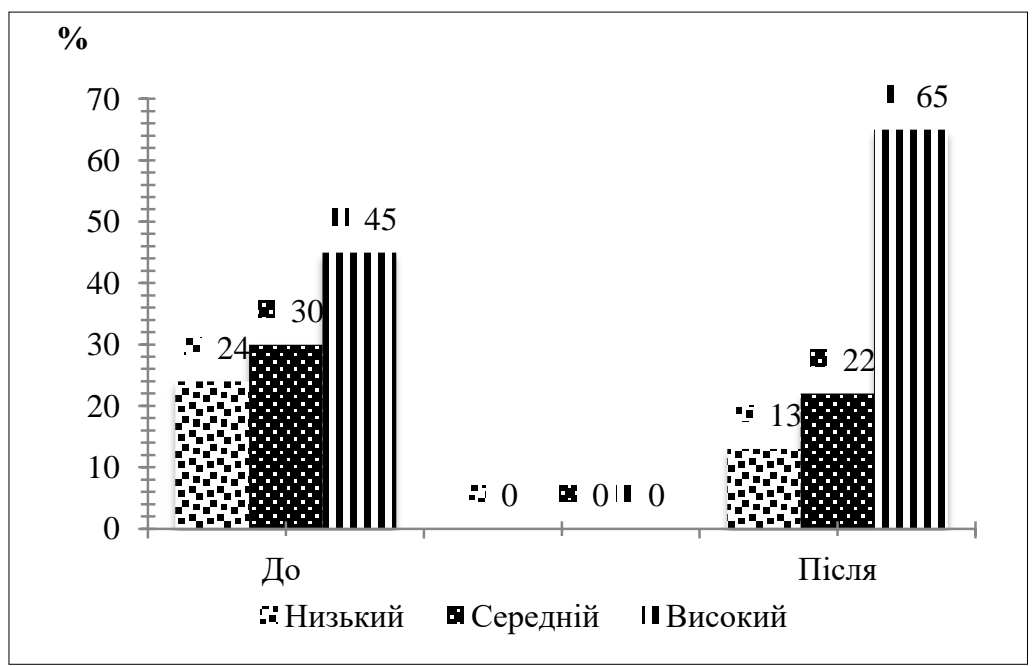

Fig. 1. Levels of development of students' spirituality ("before" and "after" implementation of the program of spiritual formation of personality)

We were formed to create Ukraine! We have been given the freedom to dream, chosen by more than one generation of our ancestors. We have to use it to write our story so that our children know their heroes, so that everyone can proudly say "This is my Ukraine". Do not ask what the state gave you, but ask yourself: what did you do for the state. It is the duty of everyone to be inspired and inspired, purpose and knowledge, experience and strength, 
courage, dedication and responsibility. In a healthy and strong spirit of society, a new generation will grow - self-respecting, nationally and spiritually conscious, committed to its people and Ukraine.

\section{SUMMARY}

The article is devoted to the role of public organizations in the life of society. Their influence on the spiritual formation of student youth. The object of this research is the process of spiritual formation of student youth. Subject of research: psychological regularities and mechanisms of spiritual formation of personality in adolescence. The purpose of the study is to establish the psychological regularities and mechanisms of activity of public organizations for the spiritual development of youth.

The influence of scientific conference activity on the spiritual development of the individual is presented in the article; the program of spiritual formation of the student's personality is developed and experimentally tested; the results of the study within the specified program were obtained.

\section{REFERENCES}

1. Балл Г.О. Психологія і духовність / Упоряд. : Г. Балл, Р. Трач// Гуманістична психологія. К: Унів. Вид-во ПУЛЬСАРИ. 2005. 279 с.

2. Боришевський М.Й. Національна самосвідомість у громадянському становленні особистості. К.: Беркут, 2000. 76 с.

3. Жигайло Н.I. Психологія духовного становлення особистості майбутнього фахівця : Монографія. Львів: Видавничий центр ЛНУ імені Івана Франка, 2008336 с.

4. Максименко С.Д. Генеза здійснення особистості : наук. монографія. К. : КММ, 2006. 255 с.

5. Максименко С.Д. Психологія особистості : Підручник. К. : КММ, 2007. $296 \mathrm{c}$.

6. Москалець В.П. Психологія особистості : навчальний посібник. К. : Центр учбової літератури, 2013. 416 с.

7. Помиткін Е.О. Психологія духовного розвитку особистості : монографія. Київ : Наш час, 2005. 278 с.

8. Савчин М.В. Духовний потенціал людини : монографія. ІваноФранківськ: Вид-во “Плай” Прикарпатського ун-ту, 2001. 203 с.

9. Blayone T., Mykhailenko O.; Kavtaradze M.; Kokhan M.; van Oostveen R.; Barber W. Profiling the digital readiness of higher education students for transformative online learning in the post-Soviet nations of Georgia and Ukraine. International Journal of Educational Technology in Higher Education. 37 (2018). URL: 
https://educationaltechnologyjournal.springeropen.com/articles/10.1186/ s41239-018-0119-9

10. Bregman, L. The Ecology of Spirituality: Meanings, Virtues, and Practices in a Post-Religious Age. Baylor University Press, 2014. Project MUSE. URL: muse.jhu.edu/book/28848.

11. Caroline H. Liu, Peter J. Robertson. Spirituality in the Workplace: Theory and Measurement. Journal of Management Inquiry. 2010. Vol. 20. Issue. 1. Page(s): 35-50 URL: https://doi.org/10.1177/1056492610374648

12. Culliford L. The Psychology of Spirituality: An Introduction. London and Philadelphia, Jessica Kingsley Publishers, 2011, 256 p.

13. Kokhan M. Kehrein E. Transfer of European experience in the development of entrepreneurial motivation. Philosophy \& psychology of leadership in business, education and government. March 15, 2019, Lviv. P. 3-6.

Information about the author: Zhyhaylo N. I., Doctor of Psychology, Professor of Management Department Ivan Franko National Universiti of Lviv 1, Universytetska str., Lviv, 79000, Ukraine

Ryzhak L. V. Ph.D., Associate Professor of the Department of Philosophy, Dean of Philosophy Faculty Ivan Franko National Universiti of Lviv 1, Universytetska str., Lviv, 79000, Ukraine 